DOI: 10.12731/2658-6649-2019-11-5-2-95-99

УДК 614.2

\title{
ДИНАМИКА СТАНДАРТИЗОВАННЫХ ПОКАЗАТЕЛЕЙ СМЕРТНОСТИ НАСЛЕНИЯ КРАСНОЯРСКОГО КРАЯ ПО ОСНОВНЫМ ПРИЧИНАМ СМЕРТИ
}

\author{
Наркевич А.Н., Миронова А.А., Дюба М.В., \\ Курбанисмаилов Р.Б.
}

В статье представлена динамика стандартизованных показателей смертности населения Красноярского края от основных причин смерти за период с 1999 по 2017 г2. В Красноярском крае за 18 лет произошло снижение как общей смертности населения, так и смертности от основных причин смерти. Однако, следует обратить внимание на отсутствие динамики смертности от злокачественных новообразований и увеличение смертности от болезней органов пищеварения.

Ключевые слова: стандартизованные показатели смертности; демография; потери населения.

\section{THE DYNAMICS OF THE STANDARDIZED MORTALITY RATES OF THE POPULATION OF THE KRASNOYARSK REGION BY MAIN CAUSES OF DEATH}

Narkevich A.N., Mironova A.A., Duba M.V., Kurbanismailov R.B.

The article presents the dynamics of standardized indicators of mortality of the population of the Krasnoyarsk region from the main causes of death for the period from 1999 to 2017. In the Krasnoyarsk region for 18 years there was a decrease in both total mortality and mortality from the main causes of death. However, attention should be paid to the lack of dynamics of mortality from malignant tumors and increased mortality from diseases of the digestive system.

Keywords: standardized mortality indicators; demography; population losses. 
Стандартизованные показатели смертности (СПС) являются наиболее объективными по сравнению с так называемыми «грубыми» или классическими показателями смертности $[1,2]$. Помимо этого, СПС позволяют сравнивать уровень смертности между территориями с различным составом населения [3].

Целью работы явился анализ динамики СПС населения Красноярского края по основным причинам смерти.

\section{Материалы и методы исследования}

Использованы данные по зарегистрированным причинам смерти за 1999-2017 гг. и базы данных с численность населения за 1999-2018 гг. СПС рассчитывались с использованием Европейского стандарта возрастной структуры населения на 100000 населения. Для анализа динамики СПС использовался показатель темпа прироста (убыли).

\section{Результаты исследования}

В 1999 году общий СПС в Красноярском крае составил 1643,1 на 100000 населения. В период с 1999 года по 2005 года данный показатель несколько возрос до 1672,2 на 100000 населения (темп прироста 1,8\%). С 2006 года общий СПС в Красноярском крае начал свое снижение с 1476,8 на 100000 населения до 1087,2 на 100000 населения.

Основными причинами смертности населения Красноярского края долгий период являлись болезни системы кровообращения (IX класс причин смерти МКБ-10), злокачественные новообразования (буквенный код C II класса причин смерти МКБ-10), болезни органов дыхания (Х класс причин смерти МКБ-10), болезни органов пищеварения (XI класс причин смерти МКБ-10), некоторые инфекционные и паразитарные болезни (I класс причин смерти МКБ-10) и внешние причины смерти (XX класс причин смерти МКБ-10). В связи с этим далее рассмотрены СПС в Красноярском крае за период с 1999 по 2017 гг. от данных причин.

В 1999 году в Красноярском крае СПС от болезней системы кровообращения составил 846,0 на 100000 населения. К 2003 году данный показатель несколько возрос до 857,3 на 100000 населения (темп прироста $-1,3 \%$ ). В последующем с 2004 года по 2017 год СПС от болезней системы кровообращения существенно снизился до 498,8 на 100000 населения (темп убыли - 37,2\%). СПС от злокачественных новообразований в Красноярском крае за период с 1999 по 2017 год практически не изменился. Так в 1999 году данный показатель составил 210,6 на 100000 
населения, а в 2017 году - 210,0 на 100000 населения. Практически не изменились также значения СПС от некоторых инфекционных и паразитарных болезней, болезней органов пищеварения и болезней органов дыхания. Так, в 1999 году в Красноярском крае СПС от некоторых инфекционных и паразитарных болезней составил 38,4 на 100000 населения, а в 2017 году - 31,9 на 100000 населения, СПС от болезней органов пищеварения в 1999 году составил 61,2 на 100000 населения, а в 2017 - 72,5 на 100000 населения, СПС от болезней органов дыхания в 1999 году составил 81,3 на 100000 населения, а в 2017 году - 55,1 на 100000 населения.

Существенных изменений претерпел СПС от внешних причин смерти. Так, в 1999 году он составил 235,5 на 100000 населения, а к 2005 году он возрос до 279,3 на 100000 населения (темп прироста - 18,6\%). С 2006 года началось стремительное снижение СПС от внешних причин смерти достигнув к 2017 году значения 128,0 на 100000 населения. Таким образом, темп убыли СПС от внешних причин смерти в Красноярском крае за период с 2005 до 2017 года составил 54,2\%.

\section{Обсуждение}

За период с 1999 по 2017 гг. отмечается снижение общего СПС на $33,8 \%$. Необходимо отметить, что СПС от злокачественных новообразований за 18 лет практически не изменился. Минимальных значений он достигал в 2007 году (201,8 на 100000 населения), максимальных - в 2008 (212,9 на 100000 населения). Темп убыли за 18 лет составил лишь 0,3\%. СПС от болезней системы кровообращения снизился на 41,0\%. Максимальных значений СПС от болезней системы кровообращения достигал в 2002 году (864,3 на 100000 населения), а минимальных - в 2017 (498,8 на 100000 населения). Темп прироста СПС от болезней органов пищеварения за 18 лет составил 18,5\%. СПС от некоторых инфекционных и паразитарных болезней снизился на $16,9 \%$, а от болезней органов дыхания на 10,0\%. Существенное снижение за 18 лет претерпел СПС от внешних причин. Данный показатель снизился на 45,6\%.

\section{Заключение}

Таким образом, в Красноярском крае за период с 1999 по 2017 гг. произошло снижение как общей смертности населения, так и смертности от основных причин смерти. Однако, следует обратить внимание на отсутствие динамики смертности от злокачественных новообразований и увеличение смертности от болезней органов пищеварения. 


\section{Список литературы}

1. Измеров Н.Ф., Тихонова Г.И., Горчакова Т.Ю. Смертность населения трудоспособного возраста в России и развитых странах Европы: тенденции последнего двадцатилетия // Вестник РАМН. 2014. №7-8. С. 121-126.

2. Зайкова 3.А. Смертность от самоубийств в Иркутской области как показатель неблагополучия общества // Социальные аспекты здоровья населения. 2014. №5.

3. Цинкер М.Ю., Кирьянов Д.А. Методы медико-демографического анализа на популяционном уровне // Вестник пермского университета. 2002. №2. С. 57-64.

\section{References}

1. Izmerov N.F., Tikhonova G.I., Gorchakova T.Yu. Smertnost' naseleniya trudosposobnogo vozrasta $v$ Rossii i razvitykh stranakh Evropy: tendentsii poslednego dvadtsatiletiya [Mortality of working-age population in Russia and developed countries of Europe: trends of the last twenty years]. Vestnik RAMN. 2014. №7-8, pp. 121-126.

2. Zaykova Z.A. Smertnost' ot samoubiystv v Irkutskoy oblasti kak pokazatel' neblagopoluchiya obshchestva [Mortality from suicides in the Irkutsk region as an indicator of social problems]. Sotsial'nye aspekty zdorov'ya naseleniya. 2014. №5.

3. Tsinker M.Yu., Kir'yanov D.A. Metody mediko-demograficheskogo analiza na populyatsionnom urovne [Methods of medical and demographic analysis at the population level]. Vestnik permskogo universiteta. 2002. №2, pp. 57-64.

\section{ДАННЫЕ ОБ АВТОРАХ}

\section{Наркевич Артем Николаевич, доцент}

Красноярский государственный медииинский университет имени профессора В.Ф. Войно-Ясенеикого

ул. Партизана Железняка, 1, г. Красноярск, 660022, Российская Федерачия

narkevichart@gmail.com

\section{Миронова Алена Андреевна, аспирант}

Красноярский государственный медииинский университет имени профессора В.Ф. Войно-Ясенеикого

ул. Партизана Железняка, 1, г. Красноярск, 660022, Российская Федерачия

2800817@mail.ru. 
Дюба Максим Владимирович, студент

Красноярский государственный медииинский университет имени профессора В.Ф. Войно-Ясенеикого

ул. Партизана Железняка, 1, г. Красноярск, 660022, Российская Федерачия

maksik-ololo@rambler.ru.

Курбанисмаилов Ренат Бадрудинович, аспирант

Красноярский государственный медицинский университет имени профессора В.Ф. Войно-Ясенеикого

ул. Партизана Железняка, 1, г. Красноярск, 660022, Российская Федерачия

krasgmu05@mail.ru

\section{DATA ABOUT THE AUTHORS}

Narkevich Artem Nikolaevich, associate professor

Krasnoyarsk state medical university

1, Partizana Zheleznyaka Str., Krasnoyarsk, 660022, Russian Federation narkevichart@gmail.com

Mironova Alena Andreevna, postgraduate

Krasnoyarsk state medical university

1, Partizana Zheleznyaka Str., Krasnoyarsk, 660022, Russian Federation 2800817@mail.ru

Duba Maxim Vladimirovich, student

Krasnoyarsk state medical university

1, Partizana Zheleznyaka Str., Krasnoyarsk, 660022, Russian Federation maksik-ololo@rambler.ru

Kurbanismailov Renat Badrudinovich, postgraduate

Krasnoyarsk state medical university

1, Partizana Zheleznyaka Str., Krasnoyarsk, 660022, Russian Federation krasgmu05@mail.ru 